\title{
Die inhoud en die doel van die Nederduitsch Hervormde Kerk se bediening, met verwysing na die ampte
}

\author{
J H Breytenbach \\ Pretoria
}

\begin{abstract}
The substance and purpose of the ministry of the Nederduitsch Hervormde Kerk, with reference to ecclesiastical offices.
\end{abstract}

For close on a decade, the Nederduitsch Hervormde Kerk van Afrika has been debating the issue of appropriate structures and patterns for its ministry. In this article it is argued that the debate not only reflects dissatisfaction with structures and patterns, but also brings to light dissatisfaction with the substance and purpose of the ministry of the Word as such. The ministry of the church should be understood in the light of the essence of being a church, which resides in the fact that the church belongs to the Lord. It is possible to belong to the Lord only on the basis of faith in the Word of God. The church, therefore, has one ministry only: the ministry of the Word. Appropriate ecclesiastical offices, structures and patterns are those that minister the Word.

\section{INLEIDING}

Tydens die 62ste Algemene Kerkvergadering het 'n rapport gedien van die studiekommissie wat benoem is om ondersoek te doen na 'bedieningstrukture, intensiewer bedieningspatrone en 'n moontlike spesifieke taakomskrywing van die werk van die predikant' (NHKA 1989:20). Die kommissie stel dat die 'noodsaaklikheid van so 'n ondersoek reeds op baie terreine van die kerk se werk intuïtief aangevoel' is (NHKA 1989:21). 
In die rapport is net sketsmatig aandag gegee aan die inhoud van die kerk se bediening, die verhouding bediening-bedieninge, die doel van die kerk se bediening en die dienswerk van die gelowige. Volgens 'n mededeling van die voorsitter van die kommissie, het die kommissie geoordeel dat dit as vanselfsprekend beskou kan word wat die kerk as inhoud en doel van sy bediening verstaan.

In hierdie artikel word die aandag egter juis op hierdie vraekompleks toegespits. Oor die afgelope dekade het daar in die kerk belangrike struktuurveranderinge plaasgevind. Enkele uitstaande voorbeelde is die vestiging van KITAL (Die Kerklike Instituut vir Toerusting van Ampsdraers en Lidmate), die SVTT (Die Sentrum vir Voortgesette Teologiese Toerusting), diakonale diensgroepe en die herstrukturering van die Ringsvergadering. Hierdie veranderinge in die struktuur van die kerk se bediening het alreeds 'n beduidende effek op die kerk se werk. Die feit dat die kommissie in sy rapport nie wesenlike struktuurveranderinge aanbeveel het nie, en die onwilligheid van die Algemene kerkvergadering om sy eie struktuur in lyn te bring met die veranderde struktuur van die Ringsvergadering, dui daarop dat die kerk nie 'n ernstige aanvoeling gehad het dat daar beduidende belemmeringe vir sy bediening in sy strukture lê nie.

Net so het die bedieningspatrone in die kerk oor die afgelope dekade merkwaardig geïntensiveer. Die predikante wat in gemeentes werk het van 1979 tot 1989 met $29 \%$ toegeneem, terwyl die getal belydende lidmate met slegs $4,9 \%$ en die totale lidmatetal met $0,3 \%$ toegeneem het. Oor dieselfde tydperk het die aantal ouderlinge wat in die kerk dien met $29,6 \%$ en die aantal diakens met $28,7 \%$ toegeneem (NHKA 1980:192; NHKA 1990:212). Die diakonale dienste is aansienlik uitgebrei. By wyse van toegespitste kursusse is die aantal lidmate wat meewerk in diakonale diensgroepe, evangelisasie en kategese verhoog en hulle vaardighede opgeskerp. Die sekretariële beampte het in die meeste gemeentes deel van die gemeentelike funksionarisse geword en tientalle predikante en gemeentes behartig hulle bediening rekenaarbekwaam. Bybelstudie, toerustingskursusse, werkswinkels, seminare en spreekure het in die bedieningspatroon van die kerk normale praktyk geword.

Hierdie ontwikkelinge in die bedieningspatroon van die kerk toon dat hy tred hou met die ontwikkelinge in die wêreld waarin hy sy bediening doen. Die voorstelle wat die kommissie voorgele het in dié verband, verdiskonteer grootliks wat reeds in die kerk aan die orde is. Die intuïtiewe aanvoeling dat daar iets met die kerk se bediening skort, lê dus op 'n ander vlak as bloot dié van die bedieningstrukture en patrone. Dit lê by 'n onduidelikheid oor die inhoud en doel van die kerk se bediening. Hierdie artikel is 'n poging om voorlopig terreinverkenning te doen na die inhoud en doel van die kerk se bediening, ten einde iets van die intuïtief-aangevoelde onbehae met sy werk en werkswyses nader te presiseer. 


\section{BEDIENING, BEDIENINGSTRUKTURE EN -PATRONE}

Die strukture en patrone wat die kerk skep om sy bediening mee te dra en in die praktyk uit te voer, is nie bloot uit die praktyk af te lei nie. Dit is deel van die praktiese teologie en daarom teologiese wetenskapuitoefening, wat beteken dat dit deeglik rekening moet hou met die Woord (De Wet 1978:5-11). Aan die ander kant is die strukture en patrone van die kerk se bediening nie nét so uit die Bybel af te lees nie. Tereg sê Pelser (1990:1) dan ook dat die keuse vir bepaalde strukture en patrone bepaal word deur " $n$ bepaalde denominasie se teologiese tradisie en eie verstaan van wat die kerk in die lig van die Skrif is en behoort te wees'.

Dit is duidelik dat daar 'n noue samehang is tussen kerkbegrip, bedieningsbegrip en die strukture en patrone waarin die bediening gestalte kry. Die strukture en patrone hang egter sekondêr saam met kerk- en bedieningsverstaan. Daarom waarborg die strukture en patrone van die kerk se bediening nié 'n regte kerkbegrip en bedieningsbegrip nie. Binne 'n denominasie kan ' $n$ verskuiwing in en van teologiese waardes plaasvind wat ' $n$ ander, en selfs verkeerde, kerkbegrip en bedieningsverstaan tot gevolg kan hê, sonder dat die bedieningstrukture en patrone daarmee saam verander (Pont 1982:8). Die samehang tussen kerk- en bedieningsbegrip en die bedieningstrukture en -patrone is in hierdie geval slegs nog histories. Dit is dus nie moontlik om ' $n$ denominasie se kerk- en bedieningsbegrip uit sy bedieningstrukture en -patrone af te lei nie.

Die samehang tussen kerk- en bedieningsbegrip is 'n primêre samehang. Hier geld die woord: 'n boom word aan sy vrugte geken. Hoe 'n denominasie sy kerkwees verstaan, bepaal uit en uit hoe hy sy bediening na inhoud en doel verstaan (Labuschagne 1987:174-446). Omgekeerd is dit ook so dat wat gesien kan word aan 'n bepaalde denominasie se bediening na inhoud en doel 'n blik gee op sy kerkbegrip.

Wanneer daar in die kerk' $n$ onbehaaglikheid bespeur word met sy bediening as sodanig, word daar geraak aan die hart van die kerk. Die onbehaaglikheid bring immers die kerk se verstaan van homself en sy roeping onvermydelik in die gedrang. Die kerk word in sy verstaan van homself en van sy roeping steeds deur twee gevare van binne bedreig: enersyds die gevaar van sekularisasie en andersyds van sakralisasie (Barth 1967:667).

Sekularisasie bedreig die kerk telkens wanneer hy uit die oog verloor dat hy dienskneg van Christus is. Dit is dan wanneer die kerk nie langer na die stem van die Goeie Herder luister nie, maar daarnaas gehoor gee aan ander stemme. Die sekularisasie van die kerk bring mee dat hy sy bediening laat bepaal deur die dringendste nood wat hy in die wêreld opmerk. Sy bediening word dan gerig op 'n eie poging om hom in sy bedreigde posisie in die wêreld te handhaaf. 
Sakralisasie bedreig die kerk telkens wanneer hy uit die oog verloor dat hy dienskneg in die wêreld is. Dan luister hy ook nie meer na die stem van die verhoogde Heer nie, maar na sy eie stem. Die sakralisasie van die kerk bring mee dat hy sy bediening laat bepaal deur sy eie geykte konvensies, belydenisse en strukture. Sy bediening word gerig op homself; op sy eie grootheid en mag, en op sy eie belangrikheid.

Wanneer die kerk toegee aan of die verleiding van sekularisasie of die versoeking van sakralisasie, hou hy op om sy roeping te vervul. Hy hou op om getuie te wees van God se vreemde genade in die wêreld. Die gesekulariseerde kerk getuig hoogstens nog aangaande die religie van die wêreld aan die wêreld; die gesakraliseerde kerk getuig net van sy eie religie aan homself. S6 word die kerk 'n blote menslike verskynsel, ' $n$ afgod soos ander menslike uitdinksels (Barth 1967:670).

In sy nadenke oor sy bediening bedreig hierdie gevare ook ons Kerk. Die ideologie van organisering, reklamering en spandering (Labuschagne 1987:314-317) kan vir die Kerk in die dwingende eise van die dag verleidelik aantreklik word. Ewe so kan dit vir die Kerk 'n sterk versoeking wees om hom in die verwarrende omstandighede waarin hy hom bevind, in homself terug te trek en sy bediening toe te spits op sy eie opbou, sy eie voortreflikheid en in 'n na binne gerigte effektiwiteit.

Om enigsins aan hierdie gevare te ontkom, moet die kerk hom steeds krities daarvan vergewis dat hy vasgeknoop bly aan die wesenlike van kerkwees. Uit die wese van die kerk vloei die roeping, en dus die bediening van die kerk voort. In samehang daarmee kry die bedieningstrukture en -patrone van die kerk hulle gestalte en vulling.

\section{DIE WESE VAN DIE KERK}

Wanneer iemand op hierdie vraag wil antwoord, staan daar verskeie moontikhede vir hom oop. Dit is egter vir geen teoloog moontlik om by die teologiese tradisie waarin hy tuis is, verby te gryp nie (Velthuysen 1988:494). Die argument wat hier verder gevoer word, sluit bewustelik aan by die reformatoriese teologie, as die teologiese tradisie waarin die kerk staan.

In die teologie van die kerkhervormers is daar teenoor die Rooms-Katolieke Kerk sterk klem gelê op die feit dat die wese van die kerk nie in die kerklike instituut met sy strukture gevind word nie. Die kerk word geglo: sy wese moet dus gesoek word in die lewende verhouding van die geloof waarin die kerk tot God staan (Kühn 1980:22). Luther het gesê dat die kerk 'die heiligen Gläubigen und die Schäflein, die ihres Hirten Stimme hören' is (Kühn 1980:22).

Calvyn druk die verbondenheid van die kerk met God uit in die woorde: '...dat al diegene, wat deur die genade van God die Vader, deur die werk van die Heilige 
Gees, deelgenote geword het van Christus, afgesonder is as die eintlike en besondere eiendom van God...' (CI iv/1, par 3).

Hierdie verhouding met God word bepaal deur die genadewerk van Jesus Christus. Hy maak die kerk moontlik (Heidelbergse Kategismus Vraag 4). Daarom kan Barth selfs sê dat die wese van die kerk Jesus Christus is, dat Jesus die kerk is (1967:6). Daarmee bedoel Barth nie 'n wesensidentifikasie nie, maar dat Christus vir die kerk die enigste bestaansgrond is (Velthuysen 1988:1).

Dit lê dus volledig in lyn met die reformatoriese denke om met Velthuysen (1988:505) saam te sê: 'Die wese van die kerk is dat dit aan die Here behoort...Dit is die een saak waarsonder die kerk nie kerk kan wees nie en waarsonder hy nie eers gedink sou kon word nie. Dit is dan ook ineens die oord waarvandaan alle ander uitsprake oor die kerk sy vulling behoort te ontvang.'

So besien, is dit duidelik dat die kerk in die wêreld 'n Fremdkörper is. Na sy wese is die kerk nie 'n menslike moontlikheid nie. Hy bestaan slegs omdat Christus leef, omdat Hy met mense 'n verbond oprig en in stand hou, omdat Hy vir Hom 'n volk in aansyn roep en as sy liggaam in die wêreld laat verskyn. Daarom kan dit ook gesê word: Die koninkryk van God is die kerk (Barth 1967:66).

In die genoemde stellings van Barth kan die predikate nooit omgeruil word nie. Dit is nie moontlik om te sê, 'die kerk is Christus', of 'die kerk is die koninkryk van God' nie. Dit is onmoontlik omdat die kerk net in Christus leef, maar Christus nie in die kerk sy lewe vind nie. Dit onderstreep die feit dat die kerk nooit 'n vrywillige vereniging van mense is nie. Die kerk kan ook nooit 'n vrywillige vereniging van mense word, wat hulle eie doelwitte nastreef nie, selfs al is dit ook watter verhewe en vroom doelwitte. Die kerk is van Christus, en hy is slegs kerk as hy van Christus bly.

Die visie op die kerk as 'n vrywillige vereniging van vroom mense is egter nie sonder invloed nie. Die negentiende-eeuse teologie het juis, onder die invloed van die rasionalistiese Verligting met sy swaar klem op die individuele mens en demokratisering, aan hierdie visie op die kerk aanvaarbaarheid gegee (Pont 1987:25-46). Hierdie kerkbeskouing het 'n eie staanplek in die moderne teologie verwerf, soos die ekklesiologie van Tillich (Kühn 1980:119), die moderne samelewingsteologieë en die sogenaamde charismatiese beweging (Van Zyl 1990:33-36) getuig.

In hierdie visie op die kerk word die wese van die kerk gesoek in die keuse asook religieuse en etiese kwaliteite van mense self, nie in die genadige behoort aan Christus nie (Pont 1987:25-46). Die wortels van hierdie kerkbeskouing kan teruggevoer word na die anabaptisme. In die teologie van die reformatore word sterk beklemtoon, teenoor die wederdoperse beskouings, dat die kerk nie anders bestaan nie as in die versameling van verbondsgedooptes. Daarom is die kerk 'n corpus per- 
mixtum en leef en werk heiliges en huigelaars nás mekaar in die een kerk (Kühn 1980:23).

Teenoor sowel die beskouing dat die kerk in die instituut gewaarborg word, as die beskouing dat die suiwer kerk in die kwaliteit van die religieuse mens verseker word, grens die reformatoriese visie hom af. Die kerk is verbondskerk wat net op die fondament van God se genadige besluit in Christus bestaan. Daarom is die kerk steeds 'n eskatologiese geloofsgrootheid, wat eers in die laaste oordeel in sy ware en laste gestalte ontbloot sal word, en nié in die aardse instituut of in die suiwer kwaliteit van sy lede hier en nou nie.

\section{DIE BEDIENING VAN DIE KERK}

Die wese van die kerk is dat hy aan die Here behoort. Hierdie indikatief bepaal die imperatief van die kerk se bediening: sy wesenlike roeping is om aan die Here te behoort. Die kerk is aan die Here behorende alleen op sterkte van die versoeningswerk van Christus. Dit bring mee dat hy as bediening niks anders het nie as die bediening van die versoening. Die kerk leef in verbondsverhouding met sy Heer, daarom is hy geroepe om in verbondsgenootskap met Christus te leef. 'Ek sal vir julle 'n God wees, en julle moet vir my 'n volk wees' (vgl Vriezen 1974:181-185).

Die kerk het sy bestaansgrond in sy behoort-aan-Christus, sy bestaansruimte in die versoen-wees-met-God en sy bestaanswyse in sy verbondgenoot-wees-van-God. Nog die Here, nog die versoening, nòg die verbond is egter die besit van die kerk. Die kerk het deel aan Christus, versoening en verbond alleen deur die geloof. Die geloof het die kerk slegs deur die genadewerking van die Heilige Gees in die getuienis aangaande Christus, sy versoening en verbond (Heidelbergse Kategismus Vraag 6).

Die getuienis aangaande die versoening deur Christus het sy verbondsvolk as gegewe ontvang in die Woord en die sakramente. Teenoor die getuienis staan die kerk magteloos: hy kan die getuienis nie verander nie, nie verbeter nie, nie vermeerder nie en nie self werksaam laat wees nie. Die kerk kan die getuienis alleen herhalend bedien. Dit is die roeping van die kerk, maar tegelyk ook sy verleentheid. Hy kan net as getuie van Christus se genadewerk die Woord en sakramente bedien, in afwagting dat God self hierdie bediening van die getuienis tot bediening van die versoening sal laat word.

Dreyer (1989:350-369) het op die problematiek van die bediening van die Woord as Woord van God in die prediking gewys. Sy definisie van prediking word graag onderskryf, ook omdat dit juis hierdie verleentheid verdiskonteer. Die definisie van Dreyer toon juis aan dat prediking (en dit geld alle gestaltes van Woordverkondiging) nie 'n blote menslike moontlikheid en aktiwiteit is nie, maar 'n pneuma- 
tologiese Woordgebeure. Dit beklemtoon dat die bediening van die Woord, en so dan ook die bediening van die sakramente, deur die Heilige Gees tot bediening van die versoening gemák word (Pieterse 1989:586-597).

Die verleentheid van die kerk met sy bediening is dat hy niks meer het om te bied as slegs die getuienis aangaande Christus in Woord en sakrament nie, 'n getuienis wat tegelyk spreek oor die versoening en die verbond. Die kerk kan nie self die versoening bring, of die verbond sluit, of 'n siel vir Christus wen nie. Hy staan enersyds magteloos teenoor die hardhorende sondaar, en andersyds teenoor die vrymag van God. Tog durf hy nie sy getuienisdiens versaak nie, omdat God nie anders as deur die bediening van Woord en sakrament die bediening van die versoening verwerklik nie.

Die reformatoriese teologie beklemtoon die primaat van die bediening van die Woord en die sakramente in dié mate dat die Woord en sakramente as die onmisbare notae ecclesia geld (Pont 1981:256). Sonder die suiwer bediening van die Woord en die regte sakramentsbediening kan die kerk nie kerk bly nie, en stort hy in duie (Calvyn CI iv/1 par 11; Barth 1967:674).

Die kerk is op sigself, in die feit van sy bestaan, alreeds getuie van die versoening en van die verbond. Maar die kerk bestaan net in die genadewerking van die Heilige Gees, wat hom deur die getuienis van die Woord en sakramente by Christus hou.

Die feit dat die kerk só, en net só, bestaan, bepaal die inhoud van die kerk se bediening. Hy kan in die wêreld nie van homself getuig nie. Sy bediening het nooit die kerk as inhoud nie, nie in sy strukture, sy eie grootheid of wat ook al nie. Die kerk se bediening kan ook nie die menss as inhoud hê nie, nie in sy eie potensiaal, of sy eie voortreflikheid, of in sy keuse vir Zhristus of watter ander kwaliteit ook al nie. Die bediening van die kerk kan alleen Christus as inhoud hê: maar dan ook net dit wat ons uit die Woord van Christus weet (Steenkamp 1990:11-12).

\section{DIE DOEL VAN DIE KERK SE BEDIENING}

Die verhouding tot Christus, waarin die kerk sy bestaansgrond vind, kry gestalte in die eienskappe van die kerk. Hoe meer die kerk hierdie eienskappe sy eie eienskappe laat word, hoe meer kry die verhouding waaruit hy leef, gestalte in die wêreld, en hoe meer word die beeld van Christus in die wêreld vertoon. Dit spreek vanself dat die kerk hom nie self hierdie eienskappe toe-eien nie. Hy ontvang dit deur die werk van die Heilige Gees.

Die eienskappe van die kerk word, soos die kerk, geglo. Die oudste belydenisse van die kerk bely dan ook hierdie eienskappe: die eenheid, heiligheid en algemeenheid van die kerk (Nicea) as die gemeenskap van die heiliges (Apostolicum). 
Die eienskappe van die kerk is objektief gefundeerd (Van Niftrik s a:184). Dit is nie eienskappe wat inklewend aan die kerk self is nie, maar dit word deur die kerk ontvang. Die kerk ontvang dit in sy behoort-aan-Christus. Hierdie in-Christus ontvange eienskappe van die kerk is tegelyk die indikatief wat geglo word, èn die imperatief wat deur die kerk gehoorsaam moet word. Hierdie indikatief kan die kerk net hoor en laat hoor deur die bediening van die Woord en die sakramente, terwyl hy die imperatief net kan gehoorsaam wanneer hy die Woord gehoorsaam.

Dit is duidelik dat die bediening van die kerk gerig is op die wese van die kerk: dat sondaars met die Here versoen sal wees. Die kerk bedien die Woord sodat sondaars in die eenheid met die kerk, as heiliges oor die hele linie van die lewe en omstandighede, die gemeenskap van die heiliges sal wees. In die intensivering van die eienskappe van kerkwees deur die bediening van die Woord en die sakramente vind die opbou van die kerk plaas, gee die kerk al meer gestalte aan wat hy reeds is.

Die objektiewe gegewenheid van die eienskappe van die kerk sny egter die misverstand af dat die bediening van die kerk op homself gerig is, asof die kerk self die doel van die bediening sou wees. Die kerk se bediening is nòg teleologies op sy eienskappe gerig, nòg word hierdie eienskappe teleologies gefundeer. Die télos van die kerk, en daarmee ook van sy bediening, is immers eskatologies bepaald. Die kerk is op pad na die voleinding, en só op pad na die verwerkliking van wat hy glo, dus ook na die vervolmaking van wat hy is. Die kerk se bediening is op hierdie eschaton gerig.

In die sin is die kerk nie statiese syn nie, maar steeds dinamiese gebeure. 'Die kerk, wat sy raison d'etre in die Here Jesus Christus vind, is met sy Here op pad om, tot eer van die Here, kerk te word' (Velthuysen 1988:12).

Die doopformulier maak dit baie duidelik dat hierdie doel nie anders bereik word as deur die werking van die Heilige Gees nie, in die bediening van die Woord en die sakramente, waardeur ons verseker word dat ons aan die Here Jesus Christus behoort. Dit is $\mathrm{Hy}$ wat in ons werk en woon 'totdat ons uiteindelik in die ewige lewe as deel van die gemeente van die uitverkorenes sonder sonde sal wees' (kyk NHKA 1987:6).

Die bediening van die kerk wat hom rig op die bevordering van die eenheid, heiligheid, katolisiteit en gemeenskapsbeoefening in die kerk het dus nie die eienskappe van die kerk as doel op sigself nie. In die gehoorsaam van die imperatief van sy eienskappe is die kerk op pad na die eskatologiese télos van volmaakte eenwees met sy Heer. Dít is die doel van die kerk se bediening. So verstaan, is die kerk se bediening duidelik nie op die kerk self gerig nie, as 'n grootheid op sy eie, maar op die Heer van die kerk, van wie die kerk sy vervolmaking verwag en ontvang. 
Die eskatologiese doel van sy bediening beklemtoon die kerk se verleentheid met sy bediening. Die kerk kan immers nie self die geslaagdheid of effektiwiteit van sy bediening meet nie, omdat die doel wat hy daarmee dien, buite sy wêreld en sy oordeelsvermoë lê. Die kerk kan slegs gehoorsaam aan die imperatief van sy eienskappe op pad wees met sy bediening van die Woord, in die geloof dat God self die kerk by sy doel sal bring.

Dit is natuurlik so dat die kerk ín die wêreld leef, dat hy déúr die wêreld en sáám met die wêreld op pad is na die voleinding. Daarom moet die kerk voluit met die wêreld rekening hou en durf hy nie afsydig staan teenoor die vrae en die eise en die omstandighede wat in die wêreld aanwesig is nie. Die kerk self bestaan immers uit mense wat in die wêreld leef en werk. Die kerk mag nie uit die oog verloor dat dit mense is wat op pad is na die voleinding toe in 'n konkrete leefwêreld nie. Daarom beteken die eskatologiese doel van die bediening nié dat die kerk se bediening 'n eteriese, wêreld-uitsluitende vlug in die religieuse is nie. Dit mag juis nie so word nie, maar die kerk moet steeds mense hier en nou só met die Woord bedien dat hulle in hulle eie tyd en omstandighede op pad bly na die Here met die een, heilige, algemene kerk, die gemeenskap van die heiliges.

Indien die kerk uit die oog verloor dat sy bediening aan mense in die wêreld geskied, vervlugtig hy die eenheid van die kerk só dat sy eie waarheid hom sekte laat word (Van Selms 1952:142). Die heiligheid van die kerk word dan opgelos in 'n farisese skynheiligheid, in 'n asketiese kerkwêreld nás en teenoor die wêreld (Van Selms 1952:144; Van Niftrik s a:186). Langs die weg word die algemeenheid van die kerk verstar in kragtelose institusionalisme en internasionaliteit (Van Niftrik s a: 187). So word die gemeenskap van die heiliges omvorm tot koue tradisionalisme en verloor die kerk sy dinamiese krag as lig vir die wêreld.

Waar die kerk sy bediening tot eteriese vlug laat word in die religieuse, word sy bediening nie langer op die Heer gerig nie, maar op homself. Die bediening word preserwatisties na binne gekeer en dit stol in geykte, selfs gekanoniseerde, tradisies, strukture en patrone. Waar die kerk hom in 'n gesakraliseerde fort terugtrek en nie langer begryp dat om aan die Here te behoort ook beteken om dienskneg vir die mens te wees nie, verloor hy sy eskatologiese doel uit die oog. Dan hou hy op om saam op pad te wees na sy Here en word hy juis wêrelds.

Terwyl dit so is dat die kerk in die wêreld leef en werk, en daarom met die wêreld rekening moet hou, is dit ook so dat die kerk nie van die wêreld is nie. In sy bediening mag die kerk nooit uit die oog verloor dat hy aan die Here behoort nie, en dat hy daarom 'n Fremdkörper, selfs 'n gehate vreemdeling, in die wêreld bly. Die doel van sy bediening moet dus steeds eskatologies bepaald bly. Die kerk mag nie sy bediening in die wêreld verdig om in 'n Woord-uitsluitende, eskatologie- 
vreemde Diesseitigkeit te stol nie. 'n Vlug in die pragmatisme of die praktisisme is uiteindelik ook net 'n vlug in die religieuse. Dit mag nie, want die kerk moet steeds mense in die hier en nou só met die Woord bedien dat hulle op pad sal bly na die voleinding toe as die een heilige en algemene kerk, die gemeenskap van die heiliges, wat die Here verwag.

Wanneer die kerk uit die oog verloor dat hy nie van die wêreld is nie, word die eenheid uitgehol tot 'n leë formaliteit, en word met die uniekheid van die kerk (Van Ruler s a:131) weggedoen. Die kerk word dan 'n buurtvereniging (Van Selms 1952: 143). Die heiligheid van die kerk word onder die omstandighede gesoek in die sedelike kwaliteit van mense (Van Niftrik s a:186), wat deur programme van opvoeding en selfverwesenliking verhoog kan word. Die katolisiteit van die kerk word 'n almal-omvattendheid, selfs 'n soeke na die Geistesgemeinschaft van Tillich wat onder alle mense reeds daar is en slegs werklikheid gemaak moet word (Kühn 1980:122). So word die gemeenskap van die heiliges slegs 'n blote sosiale verskynsel, 'n liefhebbery van mense of 'n sosiale veranderingsagent. S6 verloor die kerk sy uniekheid in die wêreld en hou hy op om die sout vir die aarde te wees.

As die kerk sy bediening laat verdig tot wêreldse praktisisme en pragmatisme, word dit 'n bediening van die wêreid en nie meer van die Here nie. So 'n bediening is nie langer gerig op die Here Jesus Christus nie, maar op die kerk self. Die bediening word na binne gerig in 'n afweging van effektiwiteit en sukses na die maatstaf van die wêreld; die strukture en patrone van die bediening word uitgelewer aan die nood en modes van die wêreld, terwyl die bediening gekenmerk word deur 'n koorsige doenigheid om by te bly met die wêreld. Waar die kerk hom só aan die wêreld prysgee, verloor hy sy eskatologiese doel uit die oog. Dan verstaan hy dit nie meer dat hy alleen dienskneg vir die wêreld kan wees omdat hy aan die Here behoort nie. Dan hou die kerk op om op pad te wees na sy Heer toe, en word hy wêrelds.

Dit is duidelik dat die kerk sy eskatologiese doel nét kan nastreef as hy dinamies op pad bly deur die wêreld, sonder dat hy van die wêreld word. Dit is net moontlik wanneer die kerk die Woord hoor en gehoorsaam deur die genadige werking van die Heilige Gees. In die bediening van die Woord alleen word die kerk immers deur die Gees aan die Here Jesus Christus gebind, en net deur die gehoorsaamheid aan die Woord is die kerk een, heilig, algemeen en gemeenskap van die heiliges.

Die onlosmaaklike band tussen die wese van die kerk en die inhoud en doel van die kerk se bediening lê in die Woord, wat deur die Gees van God tot getuienis gemaak word van die versoening en verbond. Dit is die Woord wat die kerk, deur die Gees, aan die Here Jesus Christus bind in die geloof en hom as eiendom van die Here op pad na die Heer neem. 


\section{WAAR WERK DIE KERK?}

Uit die voorafgaande is dit al duidelik dat die kerk se werk nooit as 'n individualistiese doenigheid verstaan kan word nie. Die kerk is 'n gemeenskap en werk as 'n gemeenskap, nie bloot as 'n gemeenskap van mense nie, maar as 'n gemeenskap van mense wat nét bestaan in gemeenskap met Christus. Daarom werk die kerk ook nét in die gemeenskap met die Here.

Slegs as gemeenskap van Christus-behorendes en in gemeenskap met sy Here kan die kerk homself opbou: opbou deur die toevoeging van getalle, in gemeenskap met mekaar en in die gemeenskap met Christus (Barth 1967:627). Hieruit volg dit dat die kerk primêr in die erediens sy bediening beoefen. In die erediens word die Woord en die sakramente aan die gemeente in sy onderlinge gemeenskap en in sy ontmoeting met Christus bedien, word die diens van die gebede onderhou, die lofsang van die gemeente gesing, ensovoorts. Vanuit die erediens word al die ander verkondigingsgestaltes van die kerk se bediening geïnisieer en die lidmate vir hulle dienswerk toegerus.

Die kerk is egter nie slegs periodiek dáár en periodiek in gemeenskap met Christus nie. Die kerk is altyd daar en hy leef ook buite die erediens in gemeenskap met Christus. Daarom is die kerk voortdurend werksaam, soos die talle verkondigingsgestaltes van die Woord, anders as die erediens, onderstreep. In die huisgodsdiens, die pastoraat, die evangelisasiegesprek, die barmhartigheidsdiens, ensovoorts, is die kerk aan die werk.

Die konstitutiewe wat van die aktiwiteit kerklike bediening maak, is die Woord. Die kerk werk, soos hierbo aangetoon, net daar waar die Woord werk. Sonder die Woord is daar nòg kerk, nòg kerklike bediening, omdat God nie anders as deur die Woord mense aan Christus behorend maak nie. Daarom kan geen ander vaardigheid die kerk se bediening mér tot sy reg laat kom, en geen ander geskooldheid die plek daarvan beter in die kerk se bediening vul nie, as Woordgeskooldheid en Woordvaardigheid. Ook in die kerk se bediening lê die verband tussen ortodoxis en ontopraxis uitsluitlik in die gehoorsaamheid aan die Woord.

Omdat die kerk dár werk waar mense, as mense wat aan die Here behoort, die Woord gehoorsaam en laat hoor, is die bediening van die kerk nie vas te vat in bepaalde bedieningstrukture of verkondigingsgestaltes nie. Hierdie mense leef immers in alle denkbare lewenskringe, en só is die kerk daar teenwoordig en werksaam. Die kerk moet ook so in die wêreld teenwoordig wees en werk (Barth 1967: 621). Die kerk se bediening mag nie verskraal word tot die gestruktureerde aktiwiteite van die kerk nie, en die lidmaat se betrokkenheid mag nie afgeskaal word tot deelname aan hierdie gestruktureerde aktiwiteite nie. Daarom mag die bedieningstrukture en patrone in die kerk nie daartoe lei dat die lidmate se deelname aan die 
erediens of dienswerk in 'n amp of medewerking in 'n diensgroep of watter ander 'aktiewe betrokkenheid' ook al, afgespeel word teen die gewone gehoorsame lewe aan die Woord nie.

Die roeping van die lidmaat, as lidmaat van die kerk, is immers primêr die roeping om kerk te wees, dit wil sê om aan die Here te behoort. Sy betrokkenheid by die kerk kan nooit minder wees as die totale betrokkenheid by Christus nie. By Christus is hy betrokke deur die Woord wat hom aanspreek, wat hom vorm en wat sy optrede onder alle omstandighede en in elke lewenskring bepaal met sy eis om gehoorsaam te word. Slegs as die lidmaat só onder die gesag van die Woord staan, kan hy in die wêreld leef en terselfdertyd ván Christus wees. Net in hierdie allesomvattende, allesbepalende behorenheid-aan-Christus kan hy 'n dienskneg vír die wêreld maar ván die Here wees. Dit is die wyse waarop elke gelowige lidmaat sy priesterskap as gelowige uitleef (Pont 1988:404-419). S6 gehoorsaam die gelowige sy roeping, en só verrig die kerk sy bediening buite die gestruktureerde aktiwiteite en verkondigingsgestaltes om. Maar dié bedieningswyse mag nie onderwaardeer word in die kerk ter wille van ander bedieningstrukture en -patrone nie.

Die volledige lewe met Christus, en dus die lewe met die kerk, is immers die normale bestaanswyse van die gelowige. Dit is tegelyk dan ook die normale bedieningswyse van die Woord deur die kerk in die wêreld tussen erediens en erediens. In Woordgehoorsaamheid leef die kerk as 'n gemeenskap in die wêreld (Van Aarde 1990:9) kerstenend, en dra hy die suurdeeg van die Woord die wêreld in.

Om enige misverstand uit die weg te ruim, moet dit tot oormaat van duidelikheid gesê word dat dit nié beteken dat die kerk nie gestruktureerd mag werk nie, of dat so 'n gestruktureerde aktiwiteit minder bediening van die Woord is nie, of dat dit vir die kerk onbelangrik is om goed gestruktureerde en fyn beplande en netjies geprogrammeerde arbeid te verrig nie. Omdat die kerk uit mense bestaan en in die wêreld werk, is dit dikwels juis nodig dat die kerk só sal doen. Maar in die gestruktureerdheid, in die aktiewe deelname wat dit genereer, in die rade en vergaderings wat dit in die lewe bring, in al die tegniese en organisatoriese vaardighede wat dit harnas, lê as sodanig geen waarborg dat dit bediening van die versoening is nie, en daarom dat dit kerkwerk is nie.

Die waarborg dat die kerk die versoening bedien, word gegee in die werk van die Heilige Gees. Die Gees gebruik nét die Getuienis van versoening, wat aan die kerk toevertrou is. Die waarborg dat die kerk kerkwerk doen, lè dus uitsluitlik in die regte bediening van die Woord en sakramente. Daarom moet die kerk hom nie in sy strukture en patrone rig op allerlei doenighede nie, maar dárop dat die lidmate van die kerk, dus die kerk self, in gehoorsaamheid aan die Woord sal leef. Die gehoorsaamheid aan die Woord bepaal die lidmaat se betrokkenheid by die kerk, 
beide in die kerk se gestruktureerde aktiwiteite en los daarvan. In sy gehoorsaamheid aan die Woord, deur sy lidmate, verrig die kerk sy bediening.

\section{DIE PLEK VAN DIE AMPTE IN DIE KERK SE BEDIENING}

In die gereformeerde ampsbeskouing word die ampte waardeer as gawes van Christus wat aan die kerk diensbaar is. Die ampsdraer staan nie hiërargies bo die lidmaat nie, en ook nie as 'n blote pragmatiese funksionaris onder die lidmaat nie (Rossouw 1990:43-58). Die ampte is aan die kerk gegee sodat die kerk homself kan opbou en sy roeping kan nakom. 'Hierdie dienswerk [ = die ampte J H B] wat ingestel is, gesag van Christus self ontvang het en deur die Gees van God gedra word, bevorder die eenheid in die geloof, die gehoorsaamheid aan die Woord en die uitvoering van hulle roeping deur die gelowiges' (Pont 1982:5).

Dit is duidelik dat die dienswerk van die ampte nie 'n ander inhoud het as die dienswerk van die gelowiges nie, maar wel 'n ander gerigtheid. Die ampte bedien die Getuienis van die versoening, en die konstituerende in die bediening wat deur die ampte verrig word, is dat dit bediening van die Woord is (Pont 1990). Die Woordbediening word spesifiek gerig op die kerk, om die lidmate van die kerk deur die Woord in die regte verhouding met die Here te hou, die volle implikasies van hierdie verhouding in die daaglikse lewe aan die lig te bring, sorg te dra dat die lidmate die eise van hierdie verhouding in leer en lewe gehoorsaam en onder alle omstandighede deur die troos van hierdie verhouding versterk word.

Die amp is, só besien, voluit gefundeer in die wese van die kerk. Die mense wat aan die Here behoort, ontvang van Hom die ampte as 'n gawe wat hulle dienend by Hom hou en hulle dienswerk in die wêreld bevorder. Die ampte vorm so die ruggraat van die kerk as 'n pneumatiese Christokrasie (Pont 1981:194) wat as gemeenskap in die wêreld dienend leef en werk.

Dit is dan meteens ook duidelik waarom die reformatoriese teologie nie iets soos die amp van die lidmaat ken nie (Rossouw 1990:35). Die ampte het 'n sterk binnekerklike gerigtheid en funksie: Dit het die bediening van die Woord aan die kerk op die oog, met die bedoeling dat die kerk in verbondenheid met sy Here in die wêreld sal leef (Roberts 1963:139). Die lidmate, daarenteen, is die kerk wat in die wêreld leef en die Woord in die wêreld bedien deur aan hulle verbondenheid met Christus stem en gestalte te gee.

Roberts (1963:158) kom tot die konklusie dat die besondere bedieninge wat in Efesiërs 4 beskryf word, as oorkoepelende funksie het om die lidmate toe te rus vir hulle dienswerk. Daarmee kan ingestem word. Die ampte vind ook hulle plek in die bediening van die kerk juis daar, dat hulle die lidmate van die kerk só met die Woord bedien dat hulle die Woord hoor en gehoorsaam, sodat hulle, toegerus met 
die Woord, in die wêreld kan leef, en met hulle oë gevestig op die Here op pad na die voleinding kan wees. So vervul hulle hul dienswerk as kerk en bou die kerk homself op in liefde.

Daarin lê, terloops, ook die remedie vir wat bekend is as die 'domineeskerk'. Die kerk word nie minder domineeskerk deur 'n vermenigvuldiging van ampte, funksies, aktiwiteite, en dergelike meer nie. In 'n bepaalde sin maak dit juis die kerk méér domineeskerk, omdat die werk van die kerk naderhand niks anders word nie as 'n proliferasie van die beperkte inisiatiewe, aktiwiteite en toerusting wat van 'n dominee of dominees uitgaan. Die kerk hou op om domineeskerk te wees wanneer die lidmate só met die Woord toegerus is dat hulle in gehoorsaamheid aan die Here van die kerk sy Woord gehoorsaam in al die veelvoudigheid van omstandighede waarin hulle leef.

Dit is opvallend dat die reformatore juis hierdie weg gevolg het om die kerk aan die clerus van Rome te ontworstel. Die reformatoriese tradisie onderskei in prinsiep slegs twee ampte: dié van die presbiter en diaken (Pont 1981:199). Die amp van presbiter word verder verdeel in die ampte van doktore, dienaars van die Woord en ouderlinge. Hoewel die spesifieke vormgewing van hierdie ampte nie by al die kerke van die reformasie eenders is nie (Pont 1981:199-216), is die onderskeidende kenmerke van die ampte konstant behou. Die doktore is belas met die onderrig en die opleiding, die dienaars van die Woord met prediking en sakramentbediening, die ouderlinge met opsig en kerkregering en die diakens met versorging en vertroosting.

Daarmee is die kontoere gegee waarbinne die onderskeie ampte ook in ons kerk se bediening funksioneer. Dit is duidelik dat dit nie hier gaan om 'n struktuur wat aan die norme van doeltreffende bestuur gemeet kan word of daaraan moet voldoen nie. Dit gaan om 'n heel ander saak: om hulle wat aan die Here behoort, by die Here en aan die Here gehoorsaam te hou as 'n pneumatiese Christokrasie. Dit kan die ampte op geen ander wyse doen nie as deur die Woord te bedien, in sy appellerende, dissiplinerende en vertroostende krag.

By die verskeidenheid van vormgewing aan die ampte by die reformatore, is dit merkwaardig in watter mate die onderskeidende kenmerke van die ampte prakties gevul is met die kenmerkende in elke amp. So is daar aan die prediking, as die primêre taak van die bedienaar van die Woord, besondere voorrang en omvang gegee. In die St Pierre in Genêve is nie minder nie as vier keer per Sondag en vier keer per week gepreek. Pastorale besoeke moes só gereël word dat dit nie met die predikant se preekwerk inmeng nie. Die feit dat die opsig en regeertaak van die ouderling gerig is daarop om die lidmate in gehoorsaamheid aan die Woord te hou, word onderstreep deur die hoë frekwensie van die huisbesoek: tot so hoog as een keer per 
week. Die onderskeid wat getref is tussen diakens wat die siekes moes besoek en vertroos en die diakens wat die armes moes besoek en versorg, lig die versorgingsen vertroostingstaak van die diakenamp sterk uit.

Die ampte, soos dit by die reformatore gefunksioneer het en in die reformatoriese teologie gefundeer word, wil juis voorkom dat die kerk 'n kerk van die clerus word, soos by Rome. Terselfdertyd wil dit voorkom dat die kerk 'n kerk van die menslike kwaliteit word, soos by die anabaptiste (Pont 1986:534-546). In die reformatoriese denke is die amp daarop gerig om die kerk as 'n korporatiewe eenheid van geregverdigde sondaars in diens van Christus te laat leef in die wêreld. Daartoe rus hy die lidmate toe met die Woord en hou hy die lidmate in gehoorsaamheid aan die Woord.

\title{
8. ENKELE OPMERKINGS OOR DIE PRAKTYK VAN DIE KERK SE BE- DIENING
}

Engelbrecht (1978:270-273) dui die basiese motief van die Calvinisme aan as:

\begin{abstract}
...én magtige poging om oor die hele linie van die menselewe na die eer en reg van God te vra en om die menselewe in sy ganse omvang voor God se ordinansies te laat buig...En die verdere ontdekking uit die Skrif self, is dat dit in die Skrif [en daarom primêr] nie oor die mens, oor sy nood, redding, geloof en lewe uit die geloof gaan nie, maar dat dit om die reg, eer en diens van die soewereine God van die Bybel gaan en dat alle denke, spreke en handel hierna moet vra en hierop gerig moet wees.
\end{abstract}

Aan hierdie peilers moet die kerk sy bediening, bedieningstrukture en -patrone meet. Dit impliseer dat die maatstaf van getalle nie vir die kerk 'n betroubare en bruikbare maatstaf is vir evaluasie nie. Dit is nie net moontlik nie, maar dit is werklik so dat die kerk by tye getalsgewys kleiner geword het, terwyl hy tog as kerk opgebou is. Die aktiwiteit van die kerk is ook nie 'n maatstaf vir die beoordeling van sy bediening nie. Daar was in die verlede immers talle georganiseerde aktiwiteite wat in die kerk geloods is en nie die eer van God, die gehoorsaamheid aan God of die opbou van die kerk gedien het nie. Omdat die kerk 'n corpus permixtum is, en omdat hy uitgelewer is aan die bedreiging en die verleiding van die wêreld, kan nò die reaksie van mense, nog die aktiewe vertoning van die kerk as maatstaf vir sy bediening geneem word. Die enigste maatstaf wat die kerk in sy bediening kan aanle om dit mee te beoordeel, is die maatstaf van getrouheid aan die Woord, van suiwer ver- 
kondiging van die Evangelie, regte bediening van die sakramente en handhawing van die tug.

Die strukture en patrone wat die kerk in sy bediening benut, moet dus aan één vereiste voldoen: Dit moet die Woord $s 6$ in die kerk laat hoor dat sy lidmate dit as kerk in die wêreld kan gehoorsaam en in leer en lewe aan die wêreld kan bedien. Die kerk se bediening kan net beoordeel word aan die wyse waarop dit die Woord onbelemmerd, suiwer en in volle omvang in elke huis in die kerk laat klink, sodat die lidmaat in die volle omvang van sy lewe as Christusbehorende en Christusgehoorsame gelowige die reg en eer van God kan dien ter wille van die wêreld. Op hierdie wyse is die kerk self struktuur waardeur die wêreld met die Woord bedien word, en nie anders nie.

In die rapport oor die bedieningstrukture word gewag gemak van 'n oorbeklemtoning van die herder-kuddemodel ten koste van die liggaammodel in die kerklike bedieningstruktuur. Dit het aanleiding gegee 'tot die eensydige aksentuering van die werk van die predikant' (NHKA 1989:37).

In hierdie poging om te probeer aandui wat die bediening van die kerk is, en watter rol die ampte daarin speel, is 'n ander weg gevolg. Hier is doelbewus weg gestuur daarvan om die bediening van die kerk te bepaal of vanuit die eienskappe van die kerk, of van die een of ander of kombinasie van die meer as honderd beelde en metafore waarmee die kerk in die Bybel beskryf word (kyk Minnear 1962:609). Hierdie benadering het die winspunt dat dit die spanning tussen die metafore van die herder-kudde en die liggaam, soos dit in die rapport na vore kom, nie slegs vermy nie, maar oplos.

In die bedieningstruktuur van die kerk meen ons om 'n kategoriale onderskeid te maak tussen die dienswerk van die ampte (herder-kuddemetafoor) en die dienswerk van die kerk (liggaammetafoor). Hierdie kategoriale onderskeid funksioneer in die teologie van die reformatore juis so dat daar nie 'n oorbeklemtoning van of die herder-kuddemodel of die liggaammodel is nie. Die ampte (herders) is die gawe van die Heer waarmee die lidmate (kudde) toegerus word om as kerk (liggaam) die wêreld te bedien met die Woord. Die klem lê in die toerusting deur die ampte steeds op die kwaliteit van die Woord wat bedien word en wat deur die Heilige Gees sélf werksaam word, en nie op die kwaliteit van die ampsdraers of lidmaat se geloof, vaardigheid of gehoorsaamheid nie (Pont 1987:43).

Die ondersoekkommissie het besondere klem gele op die funksie van die predikant as toeruster van die lidmate vir hulle dienswerk. Hierdie toerusting word gekoppel aan die toerusting van besondere groepe in die kerk, byvoorbeeld die jeugwerkgroep, die evangelisasiegroep, diensgroepe, ensovoorts. Verder word dit verbind aan besondere kursusse: erediens, prediking, huisbesoek, besondere pastoraat, 
ensovoorts. Dit wil voorkom asof daar met hierdie kursusse iets anders of iets meer beoog word as om die Woordvaardigheid van die predikante te verhoog, en of dit bedoel is om slegs die besondere groepe in die gemeente mee toe te rus. Voorbeelde hiervan is die toerusting in die besondere pastoraat (wat ten doel het om 'n basiese begrip, kennis en vaardigheid van spreekkamerhantering en berading by te bring), die kursus in jeugpastoraat (wat die predikant moet leer hoe om rekening te hou met die leeftydfases en die informele lewenstyl van jongmense) en 'n kursus in beplanning en toerustingsvaardighede (wat deurlopend as toerusting in die kerk aangebied moet word).

Hierdie toerusting kan selfs as alternatief die bediening van die Woord in die erediens vervang (NHKA 1989:71). Nás die erediens met die prediking as sentrum, word so 'n toerustingsgeleentheid voorgestel, of 'n liturgiese diens (?), Bybelstudiegeleentheid en byeenkoms met die klem op sang en musiek. In die rapport word besondere klem gelê op die lidmate se betrokkenheid by die kerk en sy werk. Die toerusting wat aan die predikant gebied moet word en wat deur hom aan die lidmate gegee moet word, asook die alternatiewe vir die erediens met die Woordverkondiging in die sentrum, is kennelik daarop gemik om aan lidmate vaardighede te leer. Die vaardighede moet hulle in staat stel om individueel en in groepverband sekere take in die kerk te verrig, aksies te onderneem en op dié wyse aktief betrokke te wees by die kerk en sy werk.

Hierdie beklemtoning kan 'n verskuiwing meebring van die sentrum van die bediening: van die Woord as bediening van die kerk na die bedieninge wat die lidmaat kan of wil onderneem (indien dit nie reeds so 'n verskuiwing aandui nie). Dit sal die fokus van die kwaliteit van die Woordbediening in die kerk wegtrek na die kwaliteite en vaardighede van die lidmaat. So 'n verskuiwing in fokus beteken 'n ingrypende verskuiwing in die teologiese denke van die kerk weg van die reformatoriese tradisie. Dit hou 'n radikale wysiging in van die kerk se kerkbegrip (Van Zyl 1990:33-36) en van die kerk se beskouing oor die priesterskap van die gelowige (Pont 1989:451-460).

Dit kan nie ontken word dat die kerk die wêreld moet ken waarin hy sy bediening verrig nie. Daarom is dit vir die kerk nodig om tred te hou met die ontwikkelinge in die wetenskappe en tegnologie, sodat hy alle hulpmiddels wat daardeur gebied word, kan gebruik in soverre dit sinvol toepasbaar is. Die kerk sal egter steeds bewus moet bly van die versoeking om sy bediening uit te lewer aan die wêreld deur Woordvaardigheid in te ruil vir mensvaardighede, en skerp daarteen moet waak.

Om aan hierdie versoeking te ontkom, is dit nodig dat elke predikant steeds bewus daarvan sal bly dat sy bediening nie minder nie, maar mér Woordbediening 
moet wees, nie minder nie, maar mér prediking, nie minder nie, maar méer toegespits op die gemeente as corpus permixum. Dit beteken dat die toerusting met die Woord aan die gesinne van die kerk, wat as kerk in die wêreld die Woord aan die wêreld bedien, 'n voorrang het bo die toerusting van groepe wat 'n kerkspesifieke taak verrig. Woordvaardigheid en Woordgehoorsaamheid by alle lidmate moet bevorder word bo gespesialiseerde mensvaardighede en vakkundighede by gemeentelike spesialisgroepe.

Dit stel aan die toerusting wat die predikant ontvang en aanbied, twee onontkombare eise. Ten eerste sal die toerusting nie gewoon 'n multi-dissiplinêre kursus of program kan wees nie. Die totale andersheid van die Woord wat die kerk bedien, sny by voorbaat die moontlikheid af om naas enige ander woord, hoe wetenskaplik begrond en menslik suiwer bedink dit ook al mag wees, te staan (Steenkamp 1990: 11-12). Daarom kan die Woord nie in die toerusting wat die kerk bied nás ander wetenskappe 'n plek kry nie, maar sal al die vakgespesialiseerde insigte, in die lig van die Woord beoordeel, in die teologiese arbeid van die kerk verdiskonteer en so geïntegreer moet word dat die kerk sy lidmate Woordmatig kan toerus. Dit is 'n onhoudbare posisie waarin hierdie toerusting die kerk plaas as dit van só 'n aard word dat die ouderlinge nie meer daaroor opsig kan hou nie, maar dat dit aan KITAL oorgelaat 'moet word (De Lange 1990). Dit weerspieël 'n kloof tussen Woord en toerusting wat die bediening van die kerk ernstige skade kan berokken.

Ten tweede mag hierdie toerusting nie geïsoleerd aangebied word nie. Dit beteken dat die toerusting nie gerig mag word op groepe en individue náas of selfs teenoor die kerk nie. Die toerusting moet steeds gerig wees op die dienswerk van die kerk as kerk in die wêreld, en daarom moet dit op die korporatiewe eenheid van die gemeente as geheel gerig word. Verder beteken dit dat die toerustingswerk nie die verantwoordelikheid van een of slegs enkele ampsdraers mag word nie. Die toerusting moet deur die totale verkondiging van die Woord aan die kerk gedra word, deur die dienswerk van die ampte. Sonder die leiding van die toerustende Woord in die teologiese denkarbeid van die doktore, die prediking en pastoraat van die dienaars van die Woord, die opsig en regering van die ouderlinge en die versorging en vertroosting van die diakens, sal taakspesifieke toerusting aan groepe nie die dienswerk van die kerk as kerk bevorder nie. Dit kan slegs daarop uitloop dat dit die liefhebbery van enkelinge in hulle groepies word.

Die vereistes dat die toerusting in die kerk toerusting met die Woord moet bly (en nie toerusting in vaardighede moet word nie), en dat die toerusting die taak van die ampte moet bly (en nie dié van die predikant of vakspesialiste moet word nie), bring die dienswerk van die doktore sterk op die voorgrond. In hulle teologiese dinkwerk sal die doktore die leiding moet neem om die toerusting wat in die kerk 
gedoen word, steeds toerusting te laat wees met die fokus op die kwaliteit van die Woord wat bedien word. Dit bring ook die dienswerk van die ander ampte opnuut op die voorgrond, omdat hulle dienswerk daarop gerig is om hierdie toerusting aan die hele kerk te bring, sodat die kerk as kerk die Woord aan die wêreld kan bedien. Slegs só kan die kerk Woordmatig sy bediening verrig en aan die verleiding ontkom om sy bediening professionalisties aan 'n programmatige werkwyse en die professionele mens ten prooi te laat val.

\section{KONKLUSIE}

Die kerk is die mense wat aan die Here behoort. In dubbele sin is die kerk 'n corpus permixtum: hy bestaan uit heiliges en huigelaars, en selfs die heiligste van die mense wat kerk is, is simul iustus et peccator. Aan hierdie kerk het die Here die bediening van die versoening toevertrou. In sy menslikheid is dit vir die kerk by voorbaat onmoontlik om hierdie roeping tot vrug te laat kom. Die feit dat sy bediening vrug dra in die wêreld, is net genade. Deur sy Gees laat God die kerk se bediening tot vrug kom. Dit is egter nie die menslike kwaliteite wat deur die Gees vrugbaar gemaak word nie, maar die vreemde Woord van God wat mense deel gee aan die versoening. Daarom het die kerk net een bediening: die bediening van die Woord.

Die kerk leef in die wêreld en verrig sy bediening in die wêreld. In hierdie wêreld dreig die kerk se menslikheid altyd om hom van sy Heer en van sy roeping te vervreem deur of sakralisasie of sekularisasie. Die enigste verweer wat die kerk teen hierdie bedreiging in homself bet, is die Woord. Die noukeurige luister na die Woord en die volhardende gehoorsaam van die Woord is die enigste manier waarop die kerk by sy Heer gehou word, en met Hom op pad kan wees in die wêreld na die voleinding.

Die primaat van die Woord is in die teologie van die reformatore besonder sterk beklemtoon. Deur die ampte is die kerk by die Woord gehou en met die Woord toegerus om onder alle lewensomstandighede die Woord te gehoorsaam. Die toespitsing van die bediening van die kerk op die Woord fokus die aandag van die reformatoriese kerk op die feit dat die vrug op sy arbeid nooit in homself gesoek moet word nie: nie in die kerk as instituut nie, en nie in die kwaliteit van die lidmate van die kerk nie.

Dreyer (1989:350-369) toon aan dat die ontwikkelinge in die teologie die Woord in die bediening van die kerk ernstig geproblematiseer het.

Grondige eksegese en uitleg van die Skrif waarborg nie meer die gesagvolle spreke van God in die prediking nie, want dit word nou vir die homileet 'n ope vraag: wat is op grond van die eksegese die 
Woord van God wat geproklameer kan word? Studente wat in hulle opleiding met hierdie wetenskaplike vraagstelling gekonfronteer word, raak verward oor die uitvoering van hulle profetiese verantwoordelikheid, om in die prediking die Woord van God an te kondig.

(Dreyer 1989:359)

Dreyer het met hierdie probleemblootlegging die kern van die onbehaaglikheid met die kerk se bediening blootgele. Indien die kerk se dienaars van die Woord nie in staat is om te bepaal wat die Woord van God is wat bedien word nie, is die kerk aan 'n volledige verwarring oor sy totale bediening prysgegee.

Daar bly vir die kerk onder sulke omstandighede drie weë oop wat hy kan gaan. Die kerk kan die wetenskaplike eksegese by die deur uitgooi en hom terugtrek in die sakrale fort van die fundamentalisme. Die kerk kan die Woord van God relativeer tot blote mensewoorde en opgaan in die sekularisme van 'n samelewingsbegeleier te wees. Nie een van hierdie twee is vir die kerk 'n heilsame weg om in te slaan nie, omdat hy daarmee sy kerkwees inboet.

Die derde weg wat die kerk kan volg, is om homself deeglik van 'n gefundeerde en sinvolle antwoord op hierdie vraag te voorsien. Daar sal toegespitste studie en onderrigwerk gedoen moet word oor hierdie saak, sodat die hele kerk, elke ampsdraer en elke lidmaat, opnuut sal kan weet wat die Woord van God in die Skrif is. Die antwoord op hierdie vraag is ' $n$ voorvereiste vir sinvolle besinning oor die bedieningstrukture en -patrone in die kerk, vir sinvolle nadenke oor die dienswerk van die ampte en die lidmate en vir sinvolle taakomskrywings, kursusse en toerusting.

Dit staan soos 'n paal bo water: As die kerk nie op grond van 'n verantwoorde en gesonde Skrifbeskouing die Woord kan proklameer nie, kan hy nie self die Woord hoor en gehoorsaam nie, en kan hy nie sy dienswerk in die wêreld verrig nie. 'n Kerk wat nie meer in staat is om gesagvol en verantwoordelik te sê 'So spreek die Here' nie, het geen bediening meer om te verrig nie.

\section{Literatuurverwysings}

Barth, K 1967. The doctrine of reconciliation, vol iv/2: Church Dogmatics. Transl by G W Bromiley. Edinbrugh: T \& T Clark.

Calvyn, J 1846. Institutio christianae religionis. Edited by Tholuck, A. Berilino: Guilelmum Thome.

De Lange, J C 1990. Omsendbrief 19/90, Toerustingskursusse. Pretoria: NHKA.

De Wet, J I 1978. Die herlewing van 'n ou definisie van Praktiese Teologie. HTS 34, 5-11. 
Dreyer, T F J 1989. 'n Poging tot 'n herdefinisie van die prediking binne die raamwerk van die Reformatoriese teologie. HTS 45, 350-369.

Engelbrecht, B J 1978. Die prinispiële patroon van die Calvinisme in Suid-Afrika, in Oberholzer, J P (red), Teologie in die kerk, 270-273. Pretoria: HAUM.

Kühn, U 1980. Kirche, bd 10: Handbuch Systematischer Theologie. Gütersloh: Gerd Mohn.

Labuschagne, J P 1987. Die historiese konteks van die 20ste eeuse samelewingsteologieë, vol 1. DD proefskrif, Universiteit van Pretoria.

Minnear, P S 1962. s v Church, idea of. IDB.

NHKA 1980. Almanak en Bybelse Dagboek. Pretoria: NHKA.

--- 1987. Diensboek. 3de hersiene uitg. Pretoria: KITAL.

-.- 1989. Agenda met bylaes vir die 62ste Algemene kerkvergadering. Pretoria: Argief van die NHKA.

--. 1990. Almanak en Bybelse Dagboek. Pretoria: Tydskrifafdeling van die NHKA.

Pelser, G M M 1990. Die bedieninge in die Nuwe Testament: 'n Ondersoek na historiese wording en prinsipiële regverdigbaarheid. Praktiese Teologie in SuidAfrika 5/1, 1-18.

Pieterse, H J C 1989. Prediking en geloofservaring: Gesprek oor die teologiese gehalte van die preek. HTS 45, 586-597.

Pont, A D 1981. Die historiese agtergronde van ons kerklike reg. Pretoria: HAUM.

--- 1982. Kerk en struktuur. HTS 38, 1-22.

--- 1986. Calvyn en die kerklike orde: Enkele opmerkings. HTS 42, 534-546.

..- 1987. Die vrye kerk: Enkele opmerkings oor die herkoms en inhoud van die opvatting. HTS $43,25-46$.

--- 1988. Die sekerheid van die geloof by Calvyn en sommige van sy navolgers. HTS 44, 404-419.

... 1989. Die priesterskap van die gelowiges soos Calvyn dit gesien het. HTS 45, 451-460.

-.- 1990. Die konstituerende elemente van die amp. Ongepubliseerde voorlegging aan die kommissie van ondersoek na die bedieningstrukture, KITAL.

Roberts, J H 1963. Die opbou van die kerk volgens die Efesebrief. Groningen: VRB.

Rossouw, P J 1990. Bedieninge in verskillende kerklike tradisies met verwysing na spesifieke paradigmas. Praktiese Teologie in Suid-Afrika 5/1, 43-60.

Steenkamp, J J 1990. Die eiesoortigheid van die Evangelie. Leer-en Lewenskwessies in Suid-Afrika 13/2,11-12.

Van Aarde, A G 1990. Predikant is nie politieke leier, maatskaplike direkteur of volksleier nie. Die Hervormer 82/12, 9 \& 14.

Van Niftrik, G C s a. Kleine Dogmatiek. 3de Druk. Nijkerk: Callenbach. 
Van Ruler, A A s a. Ik geloof: De Twaalf Artikelen van het geloof in morgenwijdingen. Sde Druk. Nijkerk: Callenbach.

Van Selms, A 1952. Lig uit Lig: Die christelike geloof volgens die Belydenis van Nicea. Kaapstad: HAUM.

Van Zyl, F J 1990. Die 'trek en stoot' faktore wat lidmate na die sektes laat oorgaan teologies geëvalueer, in Die agenda van die vergadering van die Ring van Noordelike Pretoria, 33-36. Pretoria: Ring van Noordelike Pretoria.

Velthuysen, G C 1989. Die wese van die kerk: 'n Teologiese antwoord op 'n filosofiese vraag. HTS 44, 489-513.

Vriezen, Th C 1974. Hoofdlijnen der theologie van het Oude Testament. 4de Druk. Wageningen: H Veenman \& Zonen. 